\title{
REGULATION AND VOICE IN RESIDENTIAL AGED CARE IN NEW ZEALAND
}

\author{
Katherine Ravenswood \\ New Zealand Work Research Institute, AUT University \\ kravensw@aut.ac.nz
}

\begin{abstract}
This paper seeks to explain why employment conditions have persistently remained low in this sector. It does this through examining employee voice (representative and direct) in residential aged care. This paper presents findings on the role of employee voice in four case studies of four New Zealand residential aged care facilities. It examines voice at both the organisational and national level and identifies key barriers to improved conditions for employees in residential aged care.
\end{abstract}

\section{Introduction}

Residential aged care is an increasingly significant sector owing to the aging population, therefore aging workforce, in combination with increasing demand for care in the near and more distant future (Badkar, 2009; Carryer, Hansen \& Blakey, 2010; Kiata, Kerse \& Dixon, 2005; Lazonby, 2007). The workforce in residential aged care is highly feminised and increasingly ethnically diverse. Residential aged care is low paid work, with registered nurses often paid less in residential aged care than in other settings. Caregivers in particular are disadvantaged, with average hourly rates paying little more than the national minimum wage (Lazonby, 2007). Work conditions are often a result of the desire on the part of owners to restrain rising staffing costs. This has been achieved through delegation of more complex tasks to unqualified caregivers (Networkers, 2005); increasing workload (Carryer et al., 2010; Haultain, 2011); and low staffing levels (Carryer et al., 2010; Haultain, 2011; Kiata et al., 2005; Networkers, 2005).

Given the increasing labour demand, it would seem logical for residential aged care to focus on better employment conditions that both attract and keep labour in this sector. Proponents of employee voice, or participation, have long argued that if 'effective', employee voice should work to improve employment conditions (Cox et al., 2006). This paper therefore considers the role of employee voice in workplace conditions, at an organisational and national level.

\section{Defining Employee Voice}

There are a number of terms, for example industrial democracy, employee voice, and employee involvement that are often used interchangeably to indicate employee participation. It has indeed been noted that 'one of the biggest problems with the literature on participation is the lack of a clear and unambiguous definition of its subject matter' (Marchington, 2005, p. 26). There are subtle differences in nuance between these terms, however the term used in this paper is that of employee voice. Employee voice refers here to structures and mechanisms for employees to be involved in, and influence, decision making in the workplace.

Voice may encompass a broad range of organisational structures and mechanisms (Busck et al., 2010) and has also been used to refer to information sharing, consultation, negotiation and co-determination (Howes, 2007), sharing of ideas and grievance airing (Wood \& Wall, 2007). It is agreed in the literature that voice allows employees to influence aspects of their work and working conditions (Foley \& Polanyi, 2006; Kalleberg, Nesheim \& Olsen, 2009; Markey \& Patmore, 2011; Poole et al., 2001; Rasmussen, 2009).

Employee voice may be broadly categorised into direct, representative, and financial participation. Direct voice is when employees participate directly with managers and supervisors, rather than via a representative (Richardson et al., 2010). It may occur informally or through formal arrangements (Howes, 2007; Walters, Nichols, Connor, Tasiran \& Cam, 2005); is usually job or task oriented (Knudsen, 1995); and is usually initiated by management (Walters \& Nichols, 2007).

Indirect, or representative, voice refers to collective arrangements for employee voice (Busck et al., 2010; Howes, 2007; Knudsen, 1995). Representative voice is often associated with voice at higher, more strategic, levels of the organisation rather than task based (Kim et al., 2010; Terry, 1999). It is commonly viewed as allowing employees more substantial involvement in the decision making process than direct voice (Busck et al., 2010; Howes, 2007). Trade unions are a form of representative voice. They differ from other forms of representative voice in that they are always employee initiated and operate separately from the workplace. They have been shown to improve both employee and organisational outcomes in OHS committees (Charlwood \& Terry, 2007; Cooke, 1994; Haynes et al., 2005; 
Marchington, 1992; Markey \& Patmore, 2011; Reilly et al., 1995; Walters, 2004; Walters \& Frick, 2000).

Generally, the effectiveness of employee voice for employees is related to the level at which employees are taking part in decisions. For example, whether they have influence in how they organise their work, how policy is implemented or more strategic levels of the organisation (Knudsen, 1995; Rasmussen, 2009). The range of levels at which employee voice occurs contributes to the overall 'embeddedness' of employee voice within the organisation. Cox et al. (2006) suggest that embeddedness reflects the breadth and depth of employee voice within an organisation. Breadth reflects links between different forms of voice in the organisation and depth is 'the degree to which individual EIP [employee involvement programmes] practices and combinations of EIP involve workers in their operation' (Cox et al., 2006, p. 251).

Regulation can encourage or require employee voice. One example in New Zealand is that the Health and Safety in Employment Amendment Act 2004 requires organisations of greater than 35 employees to provide opportunity for employees to participate (Lamm, 2009). Haynes et al. (2005) expected that in New Zealand the OHS committees would over time broaden the issues they considered to include stress and fatigue as potential harm and hazards. They suggested this because of changes to the Health and Safety in Employment Amendment Act 2004 (Brough, 2002; Lamm, 2009). However, Accident Compensation Corporation does not fund stress or other 'emotional issues' (ACC, 2012).

\section{Method}

The method chosen for this research is a multiple case study approach. Case study research enables the researcher to gather information through multiple methods, and also encourages analysis at multiple levels (Baxter \& Jack, 2008; Eisenhardt, 1989). Case study methods also facilitate a focus on the viewpoints of the participants (Tellis, 1997, 1997b; Yin, 1994). The case studies were conducted at four residential aged care providers. The case organisations were chosen to represent a range of organisation structures within residential aged care. Three of the four are not-for-profit organisations.

Organisational data was sourced from organisational documentation, including policy and OHS meeting minutes and agendas as available. Interviews with both managers and employees were also conducted at each case organisation. Among the employees there were some union delegates and some OHS representatives, meaning information from interviewees at different levels of the organisation in terms of the power and voice they have was gained (Holvino, 2010). In total 23 interviews were conducted across the four case organisations.

Information was also sought at a sector level. This was gained through public reports and secondary academic research. A further three interviews were conducted at the sector level.

\section{Findings}

Overall there were limited opportunities for employee voice in the four case organisations. Two organisations stood out from for the encouragement of voice. Aged Care 3 had a manager that actively encouraged unionisation through compulsory individual negotiations with all non-union members. Aged Care 4 had multiple forms of voice, predominantly direct, including quality circles, team work and an all staff (without management) forum.

Three of the four case organisations had OHS committees. Aged Care 1 had an OHS officer who updated employees and asked for comments and issues at a regular general staff meeting. This latter organisation also had low unionisation. Despite the possibility of OHS committees covering broad issues such as workload, fatigue and stress, the issues raised at committees dealt with physical injuries and hazards.

At the industry level in New Zealand voice of employee representatives in aged care is limited structurally. Despite the Age Related Residential Care Services Agreement contracts covering staffing issues such as training and staffing levels, the two unions representing workers in aged care, the nurses' union and the caregivers' union, are not involved in the national aged care contract negotiations.

\section{Conclusion}

Union representation has been shown to be instrumental in the effectiveness of OHS committees (Charlwood \& Terry, 2007; Cooke, 1994; Haynes et al., 2005; Markey \& Patmore, 2011; Reilly et al., 1995; Walters, 2004). The findings from the four case organisations showed similar links between union voice and OHS committees. However, the strongest association of voice and good employee outcomes was where there were multiple forms of both direct, representative, union and non-union voice (Cox et al., 2006; Kim et al., 2010; Markey \& Patmore, 2011)..

Regulation of employee voice in OHS clearly influenced the occurrence of OHS committees as a form of voice, but the influence of ACC regulations meant the committees overall took a narrow approach to OHS and did not consider issues such as stress and fatigue (Brough, 2002; Lamm, 2009). While regulation to some extent encouraged employee voice in OHS, the lack of regulation is the biggest factor in the restriction of employee voice in residential aged care. The exclusion of employee voice in the negotiation of the Age Related Residential Care Agreements means that employee concerns can be overlooked at a national level in residential aged care.

\section{References}

Accident Compensation Corporation. (2012). Am I Covered. Wellington, New Zealand: Accident Compensation Corporation. Retrieved 5 November 
2012 from http://www.acc.co.nz/making-aclaim/am-i-covered/index.htm

Badkar, J. (2009). Demographic shift. The future demand for paid caregivers in a rapidly ageing society. Wellington, New Zealand: Department of Labour.

Baxter, P., \& Jack, S. (2008). Qualitative case study methodology: Study design and implementation for novice researchers. The Qualitative Report, 13(4), 544-559.

Boyd, M., Kerse, N., von Randow, M., Chelimo, C., Whitehead, N., Connolly, M., et al. (2008). Changes in aged care residents' characteristics and dependency in Auckland 1988 to 2008: Findings from OPAL 10/9/08 older persons' ability level census. Auckland, New Zealand: The University of Auckland.

Brough, P. (2005). A comparative investigation of the predictors of work-related psychological wellbeing within police, fire and ambulance workers. New Zealand Journal of Psychology, 34(2), $127-$ 134.

Busck, O., Knudsen, H., \& Lind, J. (2010). The transformation of employee participation: Consequences for the work environment. Economic and Industrial Democracy, 31(3), 285305.

Carryer, J., Hansen, C., \& Blakey, J. (2010). Experiences of nursing in older care facilities in New Zealand. Australian Health Review, 34, 1117.

Charlwood, A., \& Terry, M. (2007). 21st century models of employee representation: Structures, processes and outcomes. Industrial Relations Journal, 38(4), 320-337.

Cooke, W. N. (1994). Employee participation programs, group-based incentives, and company performance: A union-non union comparison. Industrial and Labour Relations Review, 47(4), 594-609.

Cox, A., Zagelmeyer, S., \& Marchington, M. (2006). Embedding employee involvement and participation at work. Human Resource Management Journal, 16(3), 250-267.

Eisenhardt, K. M. (1989). Building theories from case study research. Academy of Management Review, 14(4), 532-550.

Foley, J., \& Polanyi, M. (2006). Workplace democracy: Why bother? Economic and Industrial Democracy, 27(1), 173-191.

Haultain, R. (2011). Take a stand - sign the charter for quality aged care. Kai Tiaki Nursing New Zealand, 17(3), 23.
Haynes, P., Boxall, P., \& Macky, K. (2005). Non-union voice and the effectiveness of joint consultation in New Zealand. Economic and Industrial Democracy, 26(2), 229-256.

Holvino, E. (2010). Intersections: The simultaneity of race, gender and class in organization studies. Gender, Work and Organization, 17(3), 248-277.

Howes, V. (2007). Workers' involvement in health and safety management and beyond: The UK case. The International Journal of Comparative Labour Law and Industrial Relations, 23(2), 245-265.

Kalleberg, A. L., Nesheim, T., \& Olsen, K. M. (2009). Is participation good or bad for workers? Effects of autonomy, consultation and teamwork on stress among workers in Norway. Acta Sociologica, 52(2), 99-116.

Kiata, N., Kerse, N., \& Dixon, R. (2005). Residential care workers and residents: The New Zealand story. The New Zealand Medical Journal, 118(1214), 1-11.

Kim, J., MacDuffie, J. P., \& Pil, F. K. (2010). Employee voice and organizational performance: Team versus representative influence. Human Relations, 63(3), 371-394.

Knudsen, H. (1995). Employee participation in Europe. London: Sage Publications.

Lamm, F. (2009). Occupational health and safety. In E. Rasmussen (Ed.), Employment relations in New Zealand (2nd ed., pp. 168-194). Auckland, New Zealand: Pearson.

Lazonby, A. (2007). The changing face of the aged care sector in New Zealand (RPRC Working Paper 2007-1). Auckland, New Zealand: Retirement Policy and Research Centre, University of Auckland.

Marchington, M. (1992). Surveying the practice of joint consultation in Australia. Journal of Industrial Relations, 34(4), 530-549.

Marchington, M. (2005). Employee involvement: Patterns and explanations. In B. Harley, J. Hyman \& P. Thompson (Eds.), Participation and democracy at work. Essays in honour of Harvie Ramsay (pp. 20-37). Basingstoke, UK: Palgrave MacMillan.

Markey, R. (2001). Introduction: Global patterns of participation. In R. Markey, A. Hodgkinson, A. Chouraqui \& U. Veersma (Eds.), Models of employee participation in a changing environment: Diversity and interaction (pp. 3-22). Aldershot, UK: Ashgate Publishing.

Markey, R. (2007). Non-union employee representation in Australia: A case study of the Suncorp Metway Employee Council Inc. Journal of Industrial Relations, 49(2), 187-209. 
Markey, R., \& Patmore, G. (2011). Employee participation in health and safety in the Australian steel industry: Port Kembla, 1935-2006. British Journal of Industrial Relations, 49(1), 144-167.

Networkers. (2005, September). A snapshot of staffing levels in aged care services: A report to the New Zealand Nurses Organisation.. Wellington, New Zealand: New Zealand Nurses Organisation. Retrieved 16 February 2011, from http://www.nzno.org.nz/LinkClick.aspx?fileticket $=\mathrm{NUnOBFV}$-95I\%3d\&tabid $=179$

Poole, M., Lansbury, R. D., \& Wailes, N. (2001). Participation and industrial democracy revisited: A theoretical perspective. In R. Markey, P. J. Gollan, A. Hodgkinson, A. Chouraqui, \& U. Veersma (Eds.), Models of employee participation in a changing global environment: Diversity and interaction. Aldershot, UK: Ashgate.

Rasmussen, E. (2009). Employment relations in New Zealand (2nd ed.). Auckland, New Zealand: Pearson.

Reilly, B., Paci, P., \& Holl, P. (1995). Unions, safety committees and workplace injuries. British Journal of Industrial Relations, 33(2), 275-288.

Richardson, M., Danford, A., Stewart, P., \& Pulignano, V. (2010). Employee participation and involvement: Experiences of aerospace and automobile workers in the UK and Italy. European Journal of Industrial Relations, 16(1), 21-37.

Tellis, W. (1997). Introduction to case study. The Qualitative Report, 3(2).

Tellis, W. (1997b). Application of a case study methodology. The Qualitative Report, 3(3).

Terry, M. (1999). Systems of collective employee representation in non-union firms in the UK. Industrial Relations Journal, 30(1), 16-30.

Walters, D. (2004). Workplace arrangements for worker participation in OHS. In E. Bluff, N. Gunningham, \& R. Johnstone (Eds.), OHS regulation for $a$ changing world of work. Sydney, Australia: Federation Press.

Walters, D., \& Frick, K. (2000). Worker participation and the management of occupational health and safety: Reinforcing or conflicting strategies? In K. Frick, P. L. Jensen, M. Quinlan, \& T. Wilthagen (Eds.), Systematic occupational health and safety management: Perspectives on an international development (pp. 43-65). Oxford, UK: Pergamon.

Walters, D., \& Nichols, T. (2007). Worker representation and workplace health and safety. Basingstoke, UK: Palgrave MacMillan.

Walters, D., Nichols, T., Connor, J., Tasiran, A. C., \& Cam, S. (2005). The role and effectiveness of safety representatives in influencing workplace health and safety (Research report 363). London: Health and Safety Executive.

Wood, S., \& Wall, T. D. (2007). Work enrichment and employee voice in human resource managementperformance studies. The International Journal of Human Resource Management, 18(7), 1335-1372.

Yin, R. K. (1994). Case study research. Thousand Oaks, CA: Sage Publications. 